\section{RICYDE. Revista Internacional de Ciencias del Deporte} doi: $10.5232 /$ ricyde

Rev. int. cienc. deporte

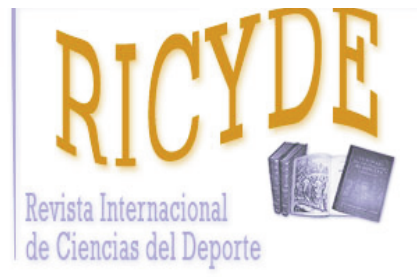

RICYDE. Revista Internacional de Ciencias del Deporte VOLUME XIV - YEAR XIV

Pages:136-147 ISSN:1885-3137

Issue: 52 - April - 2018

\title{
Effect of the rally length on performance according to the final action and the playing level in high-level men's volleyball \\ Efecto de la duración de la jugada sobre el rendimiento en función de la acción final y del nivel de juego en voleibol masculino de alto nivel
}

\author{
Joaquín Sánchez-Moreno¹, Isabel Mesquita², José Afonso ${ }^{2}$, Antonio Millán-Sánchez ${ }^{1}$ \& Aurelio Ureña ${ }^{1}$
}

1. Facultad de Ciencias del Deporte, Universidad de Granada. España

2. Centre of Research, Education, Innovation and Intervention in Sport. Faculty of Sport, University of Porto. Portugal

\begin{abstract}
The aim of this study was to analyze how rally length affected performance according to the final action of the rally and the playing level, as well as to identify potential critical rallies associated with rally length in high-level men's volleyball. Thirty-one matches $(5,438$ rallies) of the top ranking national teams were sampled from two of the premier worldwide competitions: Men's World Championship and Men's World League. Rallies between eight and ten seconds emerged as critical incidents of the game, changing the general trend in performance according to the final action of the rally (attack point or attack error with or without opposite team's contact). Rallies longer than ten seconds seemed to balance the chances of success between both teams, with the team in the side-out phase losing the initial advantage of being the first team to attack. Differences were found among teams of similar level, suggesting that the ability to efficiently manage some game situations might be attributed to team's features. Coaches may deliver drills with varying playing styles and strategies depending on the length of the really, determining the degree of risk according to the length.
\end{abstract}

Key words: performance analysis; critical moments; rally length; final actions; teams' ranking.

\section{Resumen}

El objetivo de este estudio fue analizar cómo la duración de la jugada afecta al rendimiento de los equipos en función de la acción final y del nivel de juego, así como identificar las jugadas potencialmente críticas asociadas a su duración en voleibol masculino de alto nivel. Se analizaron treinta y un partidos (5438 jugadas), donde se enfrentaban las mejores selecciones nacionales clasificadas en dos de las mejores competiciones mundiales: el Campeonato del Mundo Masculino y la Liga Mundial Masculina. Las jugadas de entre ocho y diez segundos surgieron como incidentes críticos del juego alterando la tendencia general esperada respecto al rendimiento de los equipos en función de la acción final ocurrida (puntos o errores de ataque, directos o con contacto del rival). Además, las jugadas que superaron los diez segundos parecen equilibrar las posibilidades de éxito entre ambos equipos, perdiéndose la ventaja inicial que proporciona el primer ataque al equipo en recepción. Se encontraron diferencias entre equipos de niveles de juego similares, lo que podría sugerir que la capacidad de gestionar de manera eficiente algunas situaciones del juego podría atribuirse a las características del equipo. Los entrenadores deben proponer ejercicios tomando en consideración los estilos y las estrategias de juego en función de la duración de la jugada, determinando el grado de riesgo asumido según la duración.

Palabras clave: análisis del rendimiento; momentos críticos; duración de la jugada; acciones finales; ranking de los equipos. 


\section{Introduction}

A wide body of recent research has focused on determining the role of temporal features in the match and in establishing their relationship with performance in team sports (Argolo, 2015; Granatelli et al., 2014; Torres-Luque, Sánchez-Pay, Fernández-García, \& Palao, 2014). Analysis of temporal features in sport is usually focused on identifying which incidents or moments of the game are decisive for the final result (Ferreira, Volossovitch, \& Sampaio, 2014). Hughes, Dawkins, David, \& Mills (1998) defined critical moments of the game as moments that are more decisive than others for the final outcome and, therefore, must be managed in an appropriate way due to its weight on the teams' success. In team sports, previous studies suggested that the last periods of match presented a determinant role in the final outcome (Bar-Eli \& Tractinsky, 2000; Sampaio, Ferreira, Ibáñez, \& Ribeiro, 2004).

In volleyball, ample research has been done on critical moments, using sets as the main temporal variable. Effort has been made in analyzing different characteristics of sets, dividing sets into different units, etc. Different studies categorize sets according to temporal characteristics (starting, mid-game and final), their relevance in relation to the final outcome (non-decisional sets and decisional sets), their competitive load (inferred from the difference in its final score), differences found in the first and last fifteen points, or even according to technical time-outs (Marcelino, Sampaio, \& Mesquita, 2012; Ramos, Coutinho, Silva, Davids, \& Mesquita, 2017; Sánchez-Moreno, Afonso, Mesquita, \& Ureña, 2016). The set is considered one of the most important contextual constraints identified and could be defined as a minigame within a game (Ramos et al., 2017). Indeed, to achieve a victory it is necessary to win three almost independent sets. Teams' performance changes according to different set moments, which show different critical moments. Studies focused on the initial periods aimed to characterize the consequence of early success in a competition as a predictor of final outcome (Marcelino et al., 2012). Thus, each independent set as well as each moment of a set can modify the performance of a team.

Further exploring this avenue, Hughes \& Bartlett (2002) indicate that rally length is a performance indicator that directly affects the game in net and wall games. In volleyball, a completed rally encompasses the entirety of the play, starting with a serve and ending only when a point is scored by successfully grounding the ball on the opponent's court or when the opponent team commits a fault or receives a penalty (Fédération Internationale de Volleyball, 2015b). Volleyball is clearly scoring-dependent (Hughes \& Franks, 2004), but also timedependent since catching the ball or letting it fall (to the ground) are not valid options and rally length becomes an important scoring-related variable (Sanchez-Moreno, Marcelino, Mesquita, \& Ureña, 2015). Millán-Sánchez, Morante, Álvarez, Femia, \& Ureña (2015) indicated the particular interest of the main actions that might end rallies (such as serve, attack or block). An interesting avenue of research would thus consist in establishing how long the rally lasted when a team is in a specific phase of the game (e.g., side-out or transition), and also which team managed to score a point in those rallies. For instance, knowing how likely the final actions of the rallies occur in critical moments and what its features are may help coaches to better frame training establishing specific tasks to improve performance in these situations (SánchezMoreno et al., 2016). 
Since volleyball is characterized as a non-invasive game, direct opposition between teams can only be established with attack and block actions. The structure of the game includes different game phases (game complexes) with distinct functional dynamics. Research in this field has traditionally focused on complexes I and II (e.g., Barzouka, Nikolaidou, Malousaris, \& Bergeles, 2006; Bergeles, Barzouka, \& Nikolaidou, 2009; Gónzález-Silva, Moreno, Fernández-Echeverría, Conejero, \& Moreno, 2016; Palao, Santos, \& Ureña, 2004; Sapena et al., 2016). The most widely studied is complex I (KI or side-out phase), composed by the actions of serve-reception, setting and attack (Mesquita, Palao, Marcelino, \& Afonso, 2013). Every one of these actions aims at exerting pressure to the opponents by using all available weapons in attack, at gaining the advantage by winning a direct ball, or pressing the opponent defense to save the ball and creating a counterattack as easily as possible (Zetou, Moustakidis, Tsigilis, \& Komninakidou, 2007). It is important to at least consider whether the team winning the rally started serving or receiving the serve, as the diverse game phases present specific internal dynamics (e.g., Laporta, Nikolaidis, Thomas, \& Afonso, 2015). Therefore, it is relevant to analyse whether teams playing the side-out or serving present different likelihoods of success depending on rally length.

Competition level or teams' ranking has been used to analyze performance in volleyball (Palao et al., 2004; Sattler, Hadžić, Dervišević, \& Markovic, 2015). Considering the final action of the rally of volleyball game (attack point or attack error with or without opposite team's contact) and the teams' level within the topic of critical moment in volleyball may bring about an innovative and pragmatic perspective. However, to our knowledge, no research linking rally length and performance analysis according to teams' ranking has ever been done.

The aim of this study was therefore to analyze how rally length affected performance according to the final action of the rally and the teams' ranking, as well as to identify potential critical rallies associated with rally length in high-level men's volleyball.

\section{Method}

\section{Sample and variables}

As a representative sample concerning high-level men's volleyball was sought, 5,438 rallies retrieved from 31 matches (corresponding to 121 sets) were sampled from two of the highest worldwide competitions for national teams: 2010 Men's World Championship and Men's World League.

23 matches were played between the first 12 ranked teams (Brazil, Cuba, Serbia, Italy, Russia, United States, Bulgaria, Germany, Argentina, Czech Republic, France and Spain) in the 2010 Men's World Championship. Specifically, four matches were analysed for each team in the third stage of the championship. At this phase, the matches were more levelled than in the previous stages due to the eliminatory system of competition. Moreover, a total of eight matches were analysed out of the 10 played during the final round of the FIVB 2010 Men's World League (Brazil, Russia, Serbia, Cuba, Argentina and Italy), as a representative sample of the final round.

The variables considered in this study were rally length, success of the team in the side-out phase, teams' ranking and final action of the rally. 
Rally length was bounded by the first and last legal hit by the players (Sánchez-Moreno et al., 2016; Sánchez-Moreno et al., 2015), that is (to say), the start of the rally had to coincide with the exact moment when the serving player hit the ball, while the end of the rally occurred when the last player contacted the ball before the referee whistled to stop playing. All possible events were considered and classified: (1) When the serve was failed (e.g., if the ball didn't cross to the opposite field because it hit the net, a partner, or fell into the server's own side of the court) the rally was considered completed when the ball contacted the net, the partner or the court. (2) If the serve crossed outside the permissible space (i.e., below the net or outside antennas), the rally was considered completed when the ball crossed the vertical plane of the net. (3) When a fault in playing the ball occurred (e.g., four hits, assisted hit, catch, or double contact), the illegal contact was considered the exact moment when the rally ended. (4) If the ball left the plane of the camera and no further contact within it occurred, the rally was considered completed at the exact moment when the ball had disappeared in the video. (5) When the referee annulled the rally, it was not registered.

The team in side-out phase corresponds to the team that is not serving. The teams' performance at this phase is achieved by registering who scores the point in the rally. The success of the team in the side-out phase was thus determined in two possible occurrences: losing ( No) or winning the rally (Yes). The team in the side-out phase was used as a reference to clearly establish which team was been analyzed at any time.

Teams' ranking was retrieved from the 2010 FIVB World Ranking (Fédération Internationale de Volleyball, 2015a): $1^{\text {st }}$ Brazil, $2^{\text {nd }}$ Russia, $3^{\text {rd }}$ Serbia, $4^{\text {th }}$ Cuba, $5^{\text {th }}$ United States, $6^{\text {th }}$ Italy, $7^{\text {th }}$ Bulgaria, $8^{\text {th }}$ Argentina, $9^{\text {th }}$ Germany, $12^{\text {th }}$ France, $17^{\text {th }}$ Czech Republic, and 20th Spain.

Ultimately, final action of the rally was selected by adapting the proposal of Millán-Sánchez et al. (2015). The criteria were: Serve\# (serve point), Serve= (serve error), Attack\# (attack point without opposite team's contact), Attack+ (attack point with opposite team's contact), Attack(attack error with opposite team's contact, i.e. block point), Attack= (attack error without opposite team's contact), and Others (faults).

\section{Observing training protocols}

The data was collected from pre-recorded videos. All the matches were recorded from the top of the court (i.e. about eight metres behind the end line), and the camera was positioned nearly three metres above ground level. The recording was continuous and with a framing camera that allowed observing all the events. Two observers were previously trained in order to achieve consistency in the criteria and quality in coding the data. Both had at least three years of experience in data logging on previous research in volleyball and were working as volleyball coaches at the time.

\section{Data gathering and reliability}

The data was recorded with an observational analysis software applied to volleyball: VASports (Desarrollo Software Deportivo S.L., Spain), used in previous research (Millán-Sánchez et al., 2015; Sánchez-Moreno et al., 2016). This software allowed properly registering the variables analysed to accomplish the aims of this study.

For purposes of reliability calculation, $12 \%$ of the rallies were re-analysed, surpassing the reference value of 10\% (Tabachnick \& Fidell, 2013). Cohen's Kappa ranged from 0.84 to 0.91 for inter-observer reliability, and from 0.82 to 0.92 for intra-observer reliability. Therefore, as suggested in literature (Fleiss, Levin, \& Paik, 2003), all values fulfilled the criterion of 0.75 . 


\section{Data analysis}

In order to carry on an initial analysis of data, descriptive and basic inferential statistics were applied. A data mining decision tree was used; specifically, an exhaustive CHAID growing method was applied as a visual and analytical multivariate decision support tool (Althuwaynee, Pradhan, Park, \& Lee, 2014; Kass, 1980), where the expected values of competing alternatives were calculated. This test is appropriate to analyze which variable or combination of variables better predicts a specific result (Gómez et al., 2015), and is able to cope with both categorical and continuous variables (Althuwaynee et al., 2014). Furthermore, it does not presuppose a normal distribution, as it is a non-parametric test. The cross-validation method was selected and $86.30 \%$ of correct prediction of the classification of the dependent variable was obtained. It is a flowchart-like structure in which each internal node represents a "test" on an attribute, each branch represents the outcome of the test and each leaf node represents a class label (decision taken after computing all attributes). The paths from root to leaf represent classification rules. All analyses were performed using SPSS V.20.0 (SPSS Inc., Armonk, NY, USA).

\section{Results}

The distribution of frequencies and percentages of the final action of the rally according to the success of the team in side-out phase was presented in Table 1. Attack point (Attack+) (32.97\%) and direct attack point (Attack\#) (24.73\%) were the most frequent final action of the rally. Attack + (37.91\%) was the action with which the teams in the side-out phase scored more often, whereas block (Attack-) $(24.69 \%)$ was the most frequent for the team in serve phase. Teams in serve phase obtained 231 direct serve points (Serve\#) $(13.02 \%)$ and teams in sideout phase obtained a percentage of $0.74 \%$ of technical or net faults (Others).

Table 1. Frequencies of the final action of the rally according to the game phase.

\begin{tabular}{|c|c|c|c|c|c|c|c|c|c|c|}
\hline & \multicolumn{10}{|c|}{ Final action of the rally } \\
\hline & & & Serve\# & Serve $=$ & Attack\# & Attack+ & Attack- & Attack $=$ & Others & Total \\
\hline \multirow{4}{*}{ 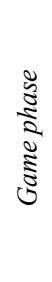 } & Team in & $\mathrm{n}$ & 231 & 0 & 270 & 404 & 438 & 388 & 43 & 1774 \\
\hline & phase & $\%$ & $13.02 \%$ & $0.00 \%$ & $15.22 \%$ & $22.77 \%$ & $24.69 \%$ & $21.87 \%$ & $2.42 \%$ & $100 \%$ \\
\hline & $\begin{array}{l}\text { Team in } \\
\text { side out }\end{array}$ & $\mathrm{n}$ & 0 & 901 & 1075 & 1389 & 143 & 129 & 27 & 3664 \\
\hline & phase & $\%$ & $0.00 \%$ & $24.59 \%$ & $29.34 \%$ & $37.91 \%$ & $3.90 \%$ & $3.52 \%$ & $0.74 \%$ & $100 \%$ \\
\hline & Total & $\mathrm{n}$ & 231 & 901 & 1345 & 1793 & 581 & 517 & 70 & 5438 \\
\hline & & $\%$ & $4.25 \%$ & $16.57 \%$ & $24.73 \%$ & $32.97 \%$ & $10.68 \%$ & $9.51 \%$ & $1.29 \%$ & $100 \%$ \\
\hline
\end{tabular}

A decision tree (exhaustive CHAID, cross validation, $86.30 \%$ of correct prediction of the classification) was carried out (Table 2) showing the following results:

The probability of winning the rally by Attack\# was $79.93 \%(\chi 2=2,025.96 ; p \leq .001$; node 4$)$ favorable to the team in side-out phase. This probability rose to $95.19 \%(\chi 2=507.39 ; p \leq .001$; node 16) if the rally lasted less than five seconds. If the rally lasted between five and ten seconds, the probability of Attack\# was favorable to the team in serve phase $(66.09 \%$; $\chi 2=507.39 ; p \leq .001$; node 17). After ten seconds the probability of obtaining Attack\# was 
balanced: $54.84 \%(\chi 2=507.39 ; p \leq .001$; node 18$)$ for the team in side-out phase and $45.16 \%$ $(\chi 2=507.39 ; p \leq .001 ;$ node 18$)$ for the team in serve phase.

Generally speaking, Attack+ was favorable to the team in side-out phase $(77.47 \%$; $\chi 2=2,025.96 ; p \leq .001$; node 2 ). In the rallies of less than five seconds and in those between five and seven, the probability of getting an Attack + was favorable to the team in side-out phase, $97.77 \%(\chi 2=656.23 ; p \leq .001$; node 8$)$ and $61.51 \%(\chi 2=656.23 ; p \leq .001$; node 9$)$, respectively. On the other hand, if the rally lasted between eight and ten seconds this probability was favorable to the team in serve phase $\left(72.59 \% ; \chi^{2}=656.23 ; p \leq .001\right.$; node 10$)$. When the rally exceeded ten seconds, as by Attack\#, the probability was balanced.

The rallies between five and seven seconds were situations where differences by teams according to the probability of obtaining an Attack+ were found. A group of teams $(1,3,4,8$ and 9) presented a $72.79 \%$ probability of winning by this action when being in side-out phase, while other teams presented a $50.00 \%$ probability. Low values were obtained of teams' ranking: $\chi 2=15.96, p=.019$, nodes 25 and 26 .

The probability of winning the rally by a block (Attack-) was higher in the team in serve phase $(75.39 \% ; \chi 2=2,025.96 ; p \leq .001$; node 3$)$. This trend was maintained although variations depending on the rally length were detected. Nevertheless, in the rallies between eight and ten seconds the probability of getting a block became favorable to the team in side-out phase (77.14\%; $\chi 2=209.42 ; p \leq .001 ;$ node 14$)$.

In the rallies of less than five seconds, differences among teams according to the probability of achieving a block were observed. A group of teams (1, 3 and 17) presented a probability of $7.59 \%$ of obtaining a block in side-out phase, while the rest of observed teams presented no data under these circumstances. Again, low values were obtained for teams' ranking: $\chi 2=16.90$, $p=.011$, nodes 27 and 28 .

The probability of losing the rally by an attack error $($ Attack $=)$ was favorable to the team in side-out phase $(75.05 \% ; \chi 2=2,025.96 ; p \leq .001$; node 5$)$. Only when the rally lasted between eight and ten seconds the probability was higher to the team in serve phase $(72.41 \%$; $\chi 2=178.62 ; p \leq .001$; node 21$)$. Finally, the probability was balanced in the rallies of more than ten seconds $(50.00 \% ; \chi 2=178.62 ; p \leq .001 ;$ node 22$)$. 
Sánchez-Moreno, J.; Mesquita, I.; Afonso, J.; Millán-Sánchez, A., \& Ureña, A. (2018). Effect of the rally length on performance according to the final action and the playing level in high-level men's volleyball. RICYDE. Revista internacional de ciencias del deporte, 52(14), 136-147. https://doi.org/10.5232/ricyde2018.05204

Table 2. Decision tree table. Dependent variable: game phase.

\begin{tabular}{|c|c|c|c|c|c|c|c|}
\hline \multirow[t]{2}{*}{ Node } & \multicolumn{3}{|c|}{ Game phase } & \multicolumn{4}{|c|}{ Primary Independent Variable } \\
\hline & $\begin{array}{c}\text { Team in } \\
\text { serve } \\
\text { phase }\end{array}$ & $\begin{array}{c}\text { Team in } \\
\text { side out } \\
\text { phase }\end{array}$ & Total & Split Values & Variable & $\begin{array}{l}\text { Chi- } \\
\text { Square }\end{array}$ & Sig. \\
\hline 0 & $32.62 \%$ & 67.38 & $100.00 \%$ & & & & \\
\hline 1 & $0.00 \%$ & $100.00 \%$ & $16.57 \%$ & Serve $=$ & Final action of the rally & 2025.96 & 0.001 \\
\hline 2 & $22.53 \%$ & $77.47 \%$ & $32.97 \%$ & Attack + & Final action of the rally & 2025.96 & 0.001 \\
\hline 3 & $75.39 \%$ & $24.61 \%$ & $10.68 \%$ & Attack- & Final action of the rally & 2025.96 & 0.001 \\
\hline 4 & $20.07 \%$ & $79.93 \%$ & $24.73 \%$ & Attack\# & Final action of the rally & 2025.96 & 0.001 \\
\hline 5 & $75.05 \%$ & $24.95 \%$ & $9.51 \%$ & Attack $=$ & Final action of the rally & 2025.96 & 0.001 \\
\hline 6 & $100.00 \%$ & $0.00 \%$ & $4.25 \%$ & Serve\# & Final action of the rally & 2025.96 & 0.001 \\
\hline 7 & $61.43 \%$ & $38.57 \%$ & $1.29 \%$ & Others & Final action of the rally & 2025.96 & 0.001 \\
\hline 8 & $2.23 \%$ & $97.77 \%$ & $18.98 \%$ & $<=4$ & Rally length (Attack+) & 656.23 & 0.001 \\
\hline 9 & $38.49 \%$ & $61.51 \%$ & $5.35 \%$ & $(4-7]$ & Rally length (Attack+) & 656.23 & 0.001 \\
\hline 10 & $72.59 \%$ & $27.41 \%$ & $3.62 \%$ & $(7-10]$ & Rally length (Attack+) & 656.23 & 0.001 \\
\hline 11 & $46.15 \%$ & $53.85 \%$ & $5.02 \%$ & $>10$ & Rally length (Attack+) & 656.23 & 0.001 \\
\hline 12 & $97.98 \%$ & $2.02 \%$ & $5.46 \%$ & $<=4$ & Rally length (Attack-) & 209.42 & 0.001 \\
\hline 13 & $62.90 \%$ & $37.10 \%$ & $2.28 \%$ & $(4-7]$ & Rally length (Attack-) & 209.42 & 0.001 \\
\hline 14 & $22.86 \%$ & $77.14 \%$ & $1.29 \%$ & $(7-10]$ & Rally length (Attack-) & 209.42 & 0.001 \\
\hline 15 & $58.89 \%$ & $41.11 \%$ & $1.66 \%$ & $>10$ & Rally length (Attack-) & 209.42 & 0.001 \\
\hline 16 & $4.81 \%$ & $95.19 \%$ & $17.60 \%$ & $<=4$ & Rally length (Attack\#) & 507.39 & 0.001 \\
\hline 17 & $66.09 \%$ & $33.91 \%$ & $4.28 \%$ & $(4-10]$ & Rally length (Attack\#) & 507.39 & 0.001 \\
\hline 18 & $45.16 \%$ & $54.84 \%$ & $2.85 \%$ & $>10$ & Rally length (Attack\#) & 507.39 & 0.001 \\
\hline 19 & $95.95 \%$ & $4.05 \%$ & $5.44 \%$ & $<=4$ & Rally length (Attack $=)$ & 178.62 & 0.001 \\
\hline 20 & $57.47 \%$ & $42.53 \%$ & $1.60 \%$ & $(4-7]$ & Rally length (Attack=) & 178.62 & 0.001 \\
\hline 21 & $27.59 \%$ & $72.41 \%$ & $1.07 \%$ & $(7-10]$ & Rally length (Attack=) & 178.62 & 0.001 \\
\hline 22 & $50.00 \%$ & $50.00 \%$ & $1.40 \%$ & $>10$ & Rally length (Attack=) & 178.62 & 0.001 \\
\hline 23 & $5.25 \%$ & $94.75 \%$ & $5.96 \%$ & $<=3$ & Rally length (Attack+) & 19.74 & 0.001 \\
\hline 24 & $0.85 \%$ & $99.15 \%$ & $13.02 \%$ & $>3$ & Rally length (Attack+) & 19.74 & 0.001 \\
\hline 25 & $50.00 \%$ & $50.00 \%$ & $2.65 \%$ & $6 ; 5 ; 2 ; 7 ; 17 ; 12 ; 20$ & Teams' ranking (Attack+; (4 - 7]) & 15.96 & 0.019 \\
\hline 26 & $27.21 \%$ & $72.79 \%$ & $2.70 \%$ & $9 ; 4 ; 3 ; 1 ; 8$ & Teams' ranking (Attack $+;(4-7])$ & 15.96 & 0.019 \\
\hline 27 & $100.00 \%$ & $0.00 \%$ & $4.01 \%$ & $6 ; 5 ; 9 ; 4 ; 2 ; 7 ; 12 ; 20 ; 8$ & Teams' ranking (Attack-; <=4) & 16.90 & 0.011 \\
\hline 28 & $92.41 \%$ & $7.59 \%$ & $1.45 \%$ & $3 ; 1 ; 17$ & Teams' ranking (Attack-; <=4) & 16.90 & 0.011 \\
\hline
\end{tabular}

\section{Discussion}

This research intends to verify whether and how rally length interacted with performance in a team sport, specifically in high-level men's volleyball. In detail, the effect of rally length on the final action of the rally and its variation according to teams' ranking were analyzed with the purpose of identifying potential critical moments in the game. 
The results of this study support the assumption that rally length is a performance indicator that directly affects the game (Hughes \& Bartlett, 2002). Rally length seems to be related to performance in volleyball, as indicated by Sánchez-Moreno, et al., (2015). The authors presented that the chance of success for the team in side out phase changes depending on the rally length, and emphasized the importance of long rallies.

In addition, this study showed that it was most frequent for the team in the side-out phase to win a rally by direct attack point or attack point actions. Palao, Santos, \& Ureña (2007) showed similar results for elite men's teams, with $49.83 \%$ of the analyzed attacks materializing in attack points for the team in side-out phase. On the other hand, block points were most frequent action for teams in the serve phase. Although in men's senior categories serve performance is related to match outcome (Silva, Lacerda, \& Joao, 2014), and each point scored in that game phase increases the odds of winning a match (Peña, Rodríguez, Buscà, \& Serra, 2013), distance to the net and constraints related to surprising a professional team in the side-out phase entail a higher frequency of block points, rather than serve points (Millán et al., 2015).

Notwithstanding that, in this study, if the rally lasted between five and ten seconds, in reference to direct attack point, or between eight and ten seconds, in reference to attack point and attack error, the probability of winning changed, and it was favorable to the team in serve phase. Moreover, the probability of winning the rally by blocking was higher in the team in serve phase. Rallies between eight and ten seconds seem to change the general trend in performance according to game phase, where the probability of winning the rally was favourable to the team in serve phase. There is an evident relation among specific moments in the rally, game phases and final actions. Some studies in high-level men's volleyball (e.g., Peña et al., 2013; Zetou et al., 2007; Zetou, Tsigilis, Moustakidis, \& Komninakidou, 2006) have shown that one of the best predictors for the team's success in the side-out phase is the number of points scored in the first attack of the rally. It is possible to infer that when the rally does not end in the first attack, the team in the serve phase has an opportunity to attack and a higher chance to win the rally. Therefore, due to these alterations that affect performance, which are able to promote disruptions on the natural game's state (Hughes et al., 1998; Hughes, Landridge, \& Dawkin, 1998), the rallies between five and eight seconds may be considered critical moments of the game.

Results further showed that when rallies exceeded ten seconds, the probability of winning by direct attack point or attack point, or the probability of losing by attack error were balanced between both teams. Previous studies had already underlined that the success of the team in the side-out phase was related to the rally length: the shorter the rally the smaller the chance of losing the point, and the longer the rally, the higher the probability of losing it (SánchezMoreno et al., 2015). Nevertheless, itt seems that the longer rallies equated the chances of success, with teams playing in side-out definitely losing the initial advantage of being the first team to attack and with teams in serve phase not being able to end the rally with the first counterattack. Sánchez-Moreno et al. (2015) emphasized the importance of analyzing long rallies and indicated that those rallies might affect the likelihood of success on the subsequent rally due to the additional physical and psychological load that is imposed. It seems logical that in rallies longer than ten seconds, where both teams can counterattack, likelihood of success can be balanced.

Rallies lasting between five and seven seconds produced differences between the teams with regard to the likelihood of scoring an attack point. Also, in rallies lasting less than five seconds differences were observed between the teams concerning the probability of achieving a block. However, such differences did not reflect a linear relationship with final ranking in the competition although values obtained were low. Since the teams' ranking did not appear to be 
a variable that differentiated the critical moments related with rally length, this study suggests that the ability to manage those actions efficiently in those periods of time might be attributed to team's features. As team sports are regulated by interdependent network structures that influence, in a dynamical way, the teams' functionality (Gonçalves, Marcelino, TorresRonda, Torrents, \& Sampaio, 2016), it can cause differentiated impact in critical moments of the game according to the play style and features of the teams. That is why imitating play schemes does not necessarily lead to the same final result, and each team must adapt their style of play to its own features to take advantage to the fullest. Two major insights for training arise from such findings. Teams must choose whether they are interested in using a more direct style of play, although it can lead to premature errors when the assumed risk is too high, especially throughout short rallies; or, alternatively, choosing a more elaborate and low-risk strategy when rallies may be longer to find the most reliable action to score a point. Such options must be aligned with the team's and opponent's features. Indeed, players use informational constraints to regulate their actions in accordance with own team's decisions in order to disrupt the opponent team's behaviours (Evans \& Eys, 2015).

Overall, the present study has provided a greater knowledge regarding the relationship between performance and rally length according to final action of the rally, as well as how such relationship varies in potential critical rallies. Specifically, rally length influences the manner in which a point is scored, as well as the likelihood of each team winning the rally. In addition, it shows a starting point about how team game profiles according to temporary factors may provide relevant information in order to progress towards a more contextualized and variability-respecting approach in match analysis.

Future research could aim to incorporate the role of the player who carries out the final action of the rally (wing spiker, opposite spiker, middle blocker, setter or libero), and also analyze if those critical rallies occur in the same periods and by the same final action of the rally in women's teams. The temporal characteristics of the women's volleyball could be quite different from the men's volleyball, increasing rally length and showing differences in the styles of play. Joao, Leite, Mesquita, \& Sampaio (2010) indicated that specific robust numbers represent that considerable variability was evident in the game-related statistics profile, as men's volleyball games were better associated with terminal actions, and women's volleyball games were characterized by continuous actions. The analysis of rally length related with critical moments in women's volleyball can provide useful information for coaches and researchers in order to better understand how temporal features affect performance.

It is important to further point out that specific moments in the rally tend to be linked to specific phases of the game. A team will thus have the advantage for scoring depending on the phase. It could thus be interesting to better calculate both the total duration of rallies and of the actions within each phase. That is, calculating the time between reception and setting or between setting and attack, in order to provide more precise and functional information.

\section{Conclusions}

Rallies between eight and ten seconds emerged as potential critical incidents of the game. These rallies seem to change the general trend in performance according to the final action that finishes the rally (Attack\#, Attack+, Attack- and Attack=). When the rally does not end with the first attack, the team in the serve phase can attack and has a greater chance to score. On the other hand, more than ten-second rallies seem to balance the chances of success between both teams (final action of the rally: Attack\#, Attack+ and Attack=), since either team might be counterattacking when the final action of the rally occurs. 
This study suggests that the ability to manage efficiently some final actions of the rallies in concrete periods of the game may be attributed to team's features. Coaches should be cautious about imitating the style of play of top ranked teams. Players' characteristics could have an important role in the final result, and could potentially be a source of frustration and decreased performance.

This study presents practical and concrete information for coaches to better manage potential critical rallies in game in men's volleyball. Coaches may propose continuous in time game exercises and determine the actions of risk for each critical time period.

\section{Acknowledgements}

This work was supported by the Spanish Science and Innovation Ministry, National Programme I + D + i: project "MasVb competitive assessment system and technical guidance for Spanish Superleague of Volleyball" under Grant DEP2011-27503.

\section{References}

Althuwaynee, O. F.; Pradhan, B.; Park, H., \& Lee, J. H. (2014). A novel ensemble decision tree-based $\mathrm{CHi}$-squared Automatic Interaction Detection (CHAID) and multivariate logistic regression models in landslide susceptibility mapping. Landslides, 11, 10631078.

https://doi.org/10.1007/s10346-014-0466-0

Argolo, J. S. (2015). Temporal analysis of goals in woman's football London Olympics game 2012. Revista brasileira de futsal e futebol, 24(7), 191-194.

Bar-Eli, M., \& Tractinsky, N. (2000). Criticality of game situations and decision making in basketball: An application on performance crisis perspective. Psychology of Sports and Exercise, 1, 27-39. https://doi.org/10.1016/S1469-0292(00)00005-4

Barzouka, K.; Nikolaidou, M. E.; Malousaris, G., \& Bergeles, N. (2006). Performance excellence of male setters and attackers in Complex I and II on volleyball teams in the 2004 Olympic Games. International Journal of Volleyball Research, 9, 19-24.

Bergeles N.; Barzouka K., \& Nikolaidou M. (2009). Performance of male and female setters and attackers on Olympic-level volleyball teams. International Journal of Performance Analysis in Sport, 9(1), 141-148.

Evans, M. B., \& Eys, M. A. (2015). Collective goals and shared tasks: interdependence structure and perceptions of individual sport team environments. Scandinavian Journal of Medicine and Science in Sports, 25(1), 139-148.

https://doi.org/10.1111/sms.12235

Fédération Internationale de Volleyball (2015a). FIVB Senior World Ranking - Men (January, 2011). Retrieved from:

http://www.fivb.org/en/volleyball/VB_Ranking_M_2011-01.asp

Fédération Internationale de Volleyball (2015b). Official volleyball rules 2015-2016. Approved by the 34th FIVB Congress 2014. Retrieved from:

http://www.fivb.org/EN/Refereeing-Rules/documents/FIVB_Volleyball_Rules_20152016_EN_V3_20150205.pdf

Ferreira, A. P.; Volossovitch, A., \& Sampaio, J. (2014). Towards the game critical moments in basketball: a grounded theory approach. International Journal of Performance Analysis in Sport, 14, 428-442.

Fleiss, J. L.; Levin, B. A., \& Paik, M. C. (2003). Statistical methods for rates and proportions (3rd ed.). Hoboken, NJ: John Wiley and Sons.

https://doi.org/10.1002/0471445428 
Gómez, M. Á.; Battaglia, O.; Lorenzo, A.; Lorenzo, J.; Jiménez, S., \& Sampaio, J. (2015). Effectiveness during ball screens in elite basketball games. Journal of Sports Sciences. 33(17), 1844-1852.

https://doi.org/10.1080/02640414.2015.1014829

Gonçalves, B.; Marcelino, R.; Torres-Ronda, L.; Torrents, C., \& Sampaio, J. (2016). Effects of emphasising opposition and cooperation on collective movement behaviour during football small-sided games. Journal of Sports Sciences, 29, 1-9.

https://doi.org/10.1080/02640414.2016.1143111

González-Silva, J.; Moreno, A.; Fernández-Echeverría, C.; Conejero, M., \& Moreno, M. P. (2016). Characteristics of the set in volleyball, in formative stages, in set win and lost. Retos, 30, 43-47.

Granatelli, G.; Gabbett, T. J.; Briotti, G.; Padulo, J.; Buglione, A.; D' Ottavio, S., \& Ruscello, B. M., (2014). Match analysis and temporal patterns of fatigue in rugby sevens. Journal of strength and conditioning research, 28(3), 728-734. https://doi.org/10.1080/02640414.2016.1143111

Hughes, M., \& Bartlett, R. M. (2002). The use of performance indicators in performance analysis. Journal of Sports Sciences, 20, 739-754. https://doi.org/10.1080/026404102320675602

Hughes, M.; Dawkins, N.; David, R., \& Mills, J. (1998). The perturbation effect and goal opportunities in soccer. Journal of Sport Sciences, 16, 20.

Hughes, M., \& Franks, I.M. (2004). Notational Analysis of Sport: systems for better coaching and performance in sport (2nd ed.). London: Routledge.

Hughes, M.; Landridge, C., \& Dawkin, N. (1998). Perturbation leading to shooting in soccer. In Hughes, M. and Tavares, F. (Eds.). Proceedings of the Notational Analysis of Sport IV World Congress (p. 33-40). Porto: FCDEF-UP.

Joao, P. V.; Leite, N.; Mesquita, I., \& Sampaio, J. (2010). Sex differences in discriminative power of volleyball game-related statistics. Perceptual and Motor Skills, 111(3), 893900. https://doi.org/10.2466/05.11.25.PMS.111.6.893-900

Kass, G. V. (1980). An exploratory technique for investigating large quantities of categorical data. Applied Statatistics, 29(2), 119-127. https://doi.org/10.2307/2986296

Laporta, L.; Nikolaidis, P.; Thomas, L., \& Afonso, J. (2015). The importance of loosely systematized game phases in sports: the case of attack coverage systems in high-level women's volleyball. Montenegrin Journal of Sports Science and Medicine, 4(1), 19-24.

Marcelino, R.; Sampaio, J., \& Mesquita, I. (2012). Attack and serve performances according to the match period and quality of opposition in elite volleyball matches. Journal of Strength and Conditioning Research, 26(12), 3385- 3391. https://doi.org/10.1519/JSC.0b013e3182474269

Mesquita, I.; Palao, J. M.; Marcelino, R., \& Afonso, J. (2013). Performance analysis in indoor volleyball and beach volleyball. In T. McGarry, P. O'Donoghue and J. Sampaio (Eds.), Routledge handbook of sports performance analysis (pp. 367-379). Oxon: Routledge.

Millán-Sánchez, A.; Morante, J. C.; Álvarez, M.; Femia, P., \& Ureña, A. (2015). Participation in terminal actions according to the role of the player and his location on the court in top-level men's volleyball. International Journal of Performance Analysis in Sport, 15, 608-619.

Palao, J. M.; Santos, J. A., \& Ureña, A. (2004). Effect of team level on skill performance in volleyball. International Journal of Performance Analysis of Sport, 4(2), 50-60. 
Palao, J. M.; Santos, J. A., \& Ureña, A. (2007). Effect of the manner of spike execution on spike performance in volleyball. International Journal of Performance Analysis of Sport, $7(2), 126-138$.

Peña, J.; Rodríguez-Guerra, J.; Buscà, B., \& Serra, N. (2013). Which skills and factors better predict winning and losing in high-level men's volleyball? Journal of Strength and Conditioning Research, 27(9), 2487-2493.

https://doi.org/10.1519/JSC.0b013e31827f4dbe

Ramos, A.; Coutinho, P.; Silva, P.; Davids, K., \& Mesquita, I. (2017). How players exploit variability and regularity of game actions in female volleyball teams. European Journal of Sport Science, 17(4). 473-481. https://doi.org/10.1080/17461391.2016.1271459

Sampaio, J.; Ferreira, A. P.; Ibáñez, S., \& Ribeiro, C. (2004). Success in the last 5 minutes of basketball close games: investigating final outcome of ball possession, duration of ball possession, number of players' involved, defensive opposition and court location. Proceedings of the World Congress of performance Analysis in Sport 6, Belfast.

Sánchez-Moreno, J.; Afonso, J.; Mesquita, I., \& Ureña, A. (2016). Dynamics between playing activities and rest time in high-level men's volleyball. International Journal of Performance Analysis in Sport, 16, 317-331.

Sánchez-Moreno, J.; Marcelino, R.; Mesquita, I., \& Ureña, A. (2015). Analysis of the rally length as a critical incident of the game in elite male volleyball. International Journal of Performance Analysis in Sport, 15(2), 620-631.

Sapena, M. I.; Parra, M.; León, J.; Fradua, L.; Benítez, J. M., \& Ureña, A. (2016) Relationship between middle hitter and setter's position and its influence on the attack zone in elite men's volleyball. International Journal of Performance Analysis in Sport, $16(2), 523-538$

Sattler, T.; Hadžić, V.; Dervišević, E., \& Markovic, G. (2015). Vertical jump performance of professional male and female volleyball players: effects of playing position and competition level. Journal of Strength and Conditioning Research, 29(6), 1486-1493. https://doi.org/10.1519/JSC.0000000000000781

Silva, M.; Lacerda, D., \& Joao, P. V. (2014). Game-Related volleyball skills that influence victory. Journal of Human Kinetics, 41(1), 173-179. https://doi.org/10.2478/hukin-2014-0045

Tabachnick, B., \& Fidell, L. (2013). Using multivariate statistics (6th ed.). Boston: Allyn and Bacon.

Torres-Luque, G.; Sánchez-Pay, A.; Fernández-García, Á. I., \& Palao, J. M. (2014). Características de la estructura temporal en tenis. Una revisión, Journal of Sport and Health Research, 6, 117-128.

Zetou, E.; Moustakidis, A.; Tsigilis, N., \& Komninakidou, A. (2007). Does effectiveness of skill in complex I predict win in men's Olympic volleyball games? Journal of Quantitative Analysis in Sport, 3, 1559-1570. https://doi.org/10.2202/1559-0410.1076

Zetou, E.; Tsigilis, N.; Moustakidis, A., \& Komninakidou, A. (2006). Playing characteristics of men's Olympic volleyball teams in complex II. International Journal of Performance Analysis in Sport, 6, 172-177. 